\title{
Synthesis and Rietveld crystal structure refinement of mackinawite, tetragonal FeS
}

\author{
A. R. LENNIE*, S. A. T. RedFerN ${ }^{\dagger}$, P. F. SChOFIELD ${ }^{\ddagger}$ AND D. J. VAUGHAN* \\ * Department of Earth Sciences, The University of Manchester, Oxford Road, Manchester, M13 9PL, UK \\ ${ }^{\dagger}$ Department of Earth Sciences, University of Cambridge, Downing Street, Cambridge, CB2 3EQ, UK \\ ${ }^{\ddagger}$ Department of Mineralogy, The Natural History Museum, Cromwell Road, London, SW7 5BD, UK
}

\begin{abstract}
Mackinawite, tetragonal $\mathrm{FeS}$, has been synthesised by reacting iron with $\mathrm{Na}_{2} \mathrm{~S}$ solutions. A Rietveld structure refinement of X-ray powder diffraction data, recorded using X-rays monochromated from synchrotron radiation with a wavelength of $0.6023 \AA$, has been performed. The structure has been refined in the tetragonal space group, $P 4 / \mathrm{nmm}$, and has the following cell parameters: $a=3.6735(4), c=5.0328(7) \AA, \mathrm{V}=67.914(24)$ $\AA^{3}$. Our refinement shows that the $\mathrm{FeS}_{4}$ tetrahedron in mackinawite is almost perfectly regular, with a much smaller distortion than has been previously reported. An improved X-ray diffraction data set is provided.
\end{abstract}

KEYWORDS: mackinawite, Rietveld structure refinement, synthesis.

\section{Introduction}

THE mineral mackinawite, first described by Evans $e t$ al. $(1962,1964)$, is identical to synthetic tetragonal iron monosulphide (Berner, 1962, 1964), an unnamed tetragonal iron sulphide mineral (Kuovo et al., 1963) and the synthetic iron sulphide 'kansite' (Meyer et al., 1958). The importance of this metastable (Davison, 1991) iron-sulphur phase is due to its role as precursor to the formation of pyrite in sedimentary and hydrothermal systems.

Mackinawite possesses a layer structure similar to that found in tetragonal $\mathrm{PbO}$ (litharge, space group $P 4 / \mathrm{nmm}$ ), with Fe and $S$ occupying the sites of $O$ and $\mathrm{Pb}$, respectively, in litharge. $\mathrm{X}$-ray diffraction patterns from natural mackinawite (Kuovo et al., 1963), and neutron (Bertaut et al., 1965) and electron (Uda, 1968) diffraction analyses of synthetic mackinawite, support this interpretation.

A structural refinement of a natural crystal of mackinawite from Outukumpu, Finland (Taylor and Finger, 1970), shows that the structure may be thought of in terms of a distorted cubic close-packed array of $\mathbf{S}$ atoms with some of the tetrahedral interstices filled with Fe. Each metal atom is at the centre of a slightly distorted tetrahedron of $\mathrm{S}$ atoms. These tetrahedra share edges forming sheets of tetrahedra which are stacked normal to the $c$-axis, with only weak van der Waals forces holding these sheets together. Mackinawite has been reported as both a metal-excess (Clark, 1966) and a sulphur deficient (Taylor and Finger, 1970) phase.

Tetragonal $\mathrm{Fe}_{1+x} \mathrm{Se}$ and $\mathrm{Fe}_{1+x} \mathrm{Te}$, which share the anti-litharge structure found in mackinawite, are reported as metal-excess chalcogenides (Tsuji et al., 1976); a compilation of data on these phases is given in Table 1.

In addition to the tetragonal iron chalcogenide phases, it is of interest to note that there exists a family of $A B_{2} X_{2}$ compounds (Hoffmann, 1988) having the $\mathrm{ThCr}_{2} \mathrm{Si}_{2}$-type structure consisting of $B_{2} X_{2}^{2-}$ layers separated by $A^{2+}$ layers. The bonding between $A^{2+}$ and $B_{2} X_{2}^{2-}$ layers appears largely ionic, but within each $B_{2} X_{2}^{2-}$ layer there is not only B-X bonding, but also an indication of some metal-metal $\mathrm{B}-\mathrm{B}$ bonding. These $B_{2} X_{2}^{2-}$ layers share the same structure as the sheets of $\mathrm{FeS}_{4}$ tetrahedra which make up mackinawite.

Several methods for synthesising mackinawite are described in the literature, including routes involving precipitation of $\mathrm{Fe}^{2+}$ (aq) by $\mathrm{H}_{2} \mathrm{~S}$, reaction of metallic Fe with $\mathrm{H}_{2} \mathrm{~S}$ in solution (Berner, 1964), and electrochemical formation (Yamaguchi and Moori, 1972). Dry synthesis of mackinawite (Takeno et al., 
TABLE 1. Properties of iron chalcogenides with tetragonal-PbO structures (space group $P 4 / n m m, Z=2$ )

\begin{tabular}{|c|c|c|c|}
\hline Iron chalcogenide & $\begin{array}{c}\mathrm{Fe}_{1+x} \mathrm{~S} \\
(x=0.00-0.07)\end{array}$ & $\begin{array}{c}\mathrm{Fe}_{1+x} \mathrm{Se} \\
(x=0.05)\end{array}$ & $\begin{array}{c}\mathrm{Fe}_{1+x} \mathrm{Te} \\
(x=0.11-0.25)\end{array}$ \\
\hline $\begin{array}{l}\text { Maximum } \\
\text { temperature of } \\
\text { stability }\end{array}$ & $\begin{array}{l}540 \mathrm{~K} \\
\text { (to NiAs-type) }\end{array}$ & $\begin{array}{l}731 \mathrm{~K} \\
\text { (to NiAs-type) }\end{array}$ & $\begin{array}{l}1200 \mathrm{~K} \\
\text { decomposes }\end{array}$ \\
\hline $\begin{array}{l}\text { Unit cell } \\
\text { dimensions } \\
\text { at } 298 \mathrm{~K}(\AA) \\
\text { Density }\end{array}$ & $\begin{array}{l}a=3.6795(8) \\
c=5.030(2) \\
c / a=1.3670(7) \\
4.28{\mathrm{~g} . \mathrm{cm}^{-3}}^{-3}\end{array}$ & $\begin{array}{l}a=3.77 \\
c=5.52 \\
c / a=1.464 \\
5.71 \mathrm{~g} \mathrm{~cm}^{-3}\end{array}$ & $\begin{array}{l}a=3.83 \\
c=6.27 \\
c / a=1.637 \\
6.85 \mathrm{~g} \mathrm{~cm}^{-3}\end{array}$ \\
\hline References & $(1,2,3)$ & $(4,5,6)$ & $(7,8)$ \\
\hline
\end{tabular}

(1) Taylor and Finger (1970)

(3) Vaughan and Craig (1978)

(5) Gronvold and Westrum (1959)

(7) Haraldsen et al. (1944)
(2) Lennie (1994)

(4) Hagg and Kindstrom (1933)

(6) Grønvold (1968)

(8) Grønvold et al. (1954)
1982) requires addition of substantial quantities of $\mathrm{Cu}, \mathrm{Co}$ or $\mathrm{Ni}$; synthesis of mackinawite from elemental $\mathrm{Fe}$ and $\mathrm{S}$ has not been achieved.

A conflicting range of values is reported for the upper temperature limit of stability for mackinawite. Kuovo et al. (1963) report that a reconstructive transition from mackinawite to hexagonal pyrrhotite (FeS) occurs at $518 \mathrm{~K}$, while Sarkar (1971) reports a temperature of between 493 to $498 \mathrm{~K}$ for the same transition. In contrast, stability limits in the much lower temperature range of 393 to $426 \mathrm{~K}$ have been reported (Takeno and Clark, 1967; Takeno, 1965a,b; Clark, 1966). These low breakdown temperatures of natural mackinawites may, however, involve addition of sulphur from surrounding minerals (Zoka et al., 1972), and would not, therefore, be expected to be relevant to the closed system.

The Rietveld refinement and synthesis experiment described here forms part of a larger study (Lennie, 1994) which provides new information on the thermal stability of mackinawite, the expansion of the unit cell with temperature, and on solid-state transformations of this phase to both hexagonal pyrrhotite $\left(\mathrm{Fe}_{1-x} \mathrm{~S}\right)$ and to greigite $\left(\mathrm{Fe}_{3} \mathrm{~S}_{4}\right)$, the thiospinel of iron.

\section{Experimental synthesis of mackinawite}

Thirty $\mathrm{cm}^{3}$ of a solution of $\mathrm{Na}_{2} \mathrm{~S}\left(20 \mathrm{~g}\right.$ of $\mathrm{Na}_{2} \mathrm{~S} \cdot 9 \mathrm{H}_{2} \mathrm{O}$ in $200 \mathrm{~cm}^{3}$ deionised water) was added slowly to 500 $\mathrm{cm}^{3}$ of an 0.5 molar acetic acid/acetate buffer $(\mathrm{pH}=$ 4.6) in which approximately $4-5 \mathrm{~g}$ of finely divided iron wire (Roncraft, Sheffield) had been previously immersed. Dissolution of the iron wire by reaction with the acetate buffer for 30 minutes or so evolved $\mathrm{H}_{2}$, providing a reducing environment. The $\mathrm{Na}_{2} \mathrm{~S}$ solution was then added slowly, and exceeded the capacity of the acetate buffer, increasing the $\mathrm{pH}$ to a value of approximately 6.5 . This solution, containing the iron wire, was allowed to stand open to the atmosphere at room temperature for 24 hours.

The iron wool generated $\mathrm{H}_{2}$ while dissolving, and this gas, trapped in the wool matte, floated the iron to the top of the solution. Mackinawite forming on the iron surface spalled off and dropped to the bottom of the flask giving good (but not entirely complete) separation of mackinawite from the iron.

After reaction, the iron wool was removed and the supernatent solution poured off. The mackinawite remaining was rinsed onto a $0.45 \mu \mathrm{m}$ filter, then rinsed several times with deaerated deionised water while a water vacuum was applied to remove the solution. While still moist, the mackinawite was placed in U-shaped aluminium foil boats approximately $2 \mathrm{~cm}$ long. After crimping both ends of the foil, these were placed in borosilicate tubes previously sealed at one end using an $\mathrm{O}_{2}-\mathrm{CH}_{4}$ flame. These tubes were partially prefilled with enough acetone to completely cover the mackinawite contained in the aluminium boat. Surplus acetone was then removed from the tube.

A number of tubes of mackinawite prepared in this way were dried together in a flask for two hours under a vacuum of $10^{-2} \mathrm{mbar}$; acetone and water removed from the sample was condensed in a liquid $\mathrm{N}_{2}$ cooled trap. When dry, the tubes were removed from the evacuated flask under an $\mathrm{O}_{2}$-free $\mathrm{N}_{2}$ atmosphere, and individually sealed, under vacuum, using an $\mathrm{O}-\mathrm{CH}_{4}$ flame. 
TABLE 2. Compositional analyses of synthetic FeS

1. ICP analysis of mackinawite dissolved in $\mathrm{HCl}$

\begin{tabular}{lcr}
\hline Element & wt.\% & atom\% \\
\hline $\mathrm{Fe}$ & 63.2 & 49.67 \\
$\mathrm{Ti}$ & 0.10 & 0.09 \\
$\mathrm{Mn}$ & 0.17 & 0.14 \\
$\mathrm{~S}$ (by difference) & 36.53 & 50.10 \\
& & \\
2. X-ray fluorescence & analysis of mackinawite \\
\hline Element & wt.\% \\
\hline $\mathrm{Cu}$ & $<0.001$ & \\
$\mathrm{Zn}$ & 0.005 & \\
$\mathrm{Ni}$ & 0.023 \\
$\mathrm{Mn}$ & 0.39 & \\
$\mathrm{Cr}$ & 0.034 & \\
$\mathrm{Ti}$ & 0.16 & \\
& \\
\hline
\end{tabular}

Initial identification of mackinawite using X-ray powder diffraction was carried out using a Philips $\mathrm{X}$ ray diffractometer, with $\mathrm{Cu}-K \alpha \mathrm{X}$-rays generated at $40 \mathrm{kV}$ and $20 \mathrm{~mA}$. Samples were mixed with amyl acetate, spread on glass slides, and dried in air. The diffraction pattern of mackinawite showed broad peaks with the peak width at half peak height in the order of $0.5^{\circ} 2 \theta$; peak positions were consistent with previously reported diffraction patterns of mackinawite. The broad peak widths are due to the small particle size of the mackinawite crystallites.

A sample was prepared for compositional analysis by dissolving a weighed amount in hydrochloric acid. After the majority of sulphide had been removed (as $\mathrm{H}_{2} \mathrm{~S}$ ) this solution was analysed by ICP spectrometry. A second sample of mackinawite powder was analysed by X-ray fluorescence to determine concentrations of impurities in the iron sulphide. The powder, pressed into a disc of boric acid at 5 tons applied pressure, was analysed using both $\mathrm{Cr}$ and $\mathrm{Rh}$ $\mathrm{X}$-ray sources on a Philips PW $1450 \mathrm{XRF}$ spectrometer. Both analyses are recorded in Table 2. The XRF analysis shows metallic impurities amounting to $0.61 \mathrm{wt} . \%$ in FeS. No fluorescence peaks due to Se were observed.

\section{High-resolution powder diffraction}

The synthetic mackinawite was further characterised by Rietveld structure refinement. High resolution powder diffraction data were recorded at Station 9.1 on the 5 Tesla wiggler beam line of the Daresbury
Laboratory Synchrotron Radiation Source. Monochromatic radiation of wavelength $0.6023 \AA$ was selected from the channel-cut Si (111) monochromator, the radiation wavelength being calibrated from the positions of six reflections of a Si NBS $640 \mathrm{~b}$ sample.

Mackinawite rapidly oxidises under ambient atmosphere conditions, and diffraction patterns were therefore collected from samples loaded directly from sealed borosilicate tubes under an inert atmosphere. This involved sealing the sample chamber of the diffractometer in a He-filled glove bag, breaking open the borosilicate sample vial, and loading mackinawite directly onto the aluminium flat plate sample holder (15 $\mathrm{mm}$ diameter, $1 \mathrm{~mm}$ deep) of the instrument. The sample chamber was continually purged with He during data collection. This mode of sample loading, and the limited amounts of sample available to us, necessarily compromised the quality of sample presentation within the diffractometer. The sample was not perfectly flat within the sample holder, and electrostatic effects meant that the sample could not be ground to as fine a powder as would normally be preferred. Nonetheless, data of sufficient quality for satisfactory Rietveld refinement were obtained.

Diffraction data were collected between 5 and $58^{\circ} 2 \theta(d=6.91$ to $0.622 \AA)$ at steps of $0.01^{\circ} 2 \theta$. Because mackinawite is extremely easily oxidized, the $\mathrm{X}$-ray wavelength was selected to be above the Fe absorption edge to reduce photo-oxidation effects. No degradation of the sample was observed when held at room temperature in the He atmosphere; using a shorter X-ray wavelength also has the advantage of giving measurements of smaller interplanar spacings.

\section{Results and discussion}

The diffraction pattern showed mackinawite as the dominant phase, although some diffraction from $\alpha$-Fe was observed. The regions $16.80-17.40^{\circ}$, $24.0-24.6^{\circ}$, and $29.5-30.1^{\circ} 20$, containing the diffraction peaks from $\alpha-\mathrm{Fe}$, were thus excluded from the Rietveld refinement. The diffraction pattern used for the refinement is illustrated in Fig. 1.

The raw diffraction pattern was prepared for Rietveld refinement using the program MPREP, and refined using MPROF in the Powder Diffraction Program Library of Murray et al. (1990). The background was fitted with a polynomial curve; an overall scale factor, zeropoint, and preferred orientation factor (for orientation parallel to (001)) were also used. An asymmetric pseudoVoigt line shape was employed. The structure proposed by Uda (1968) (space group $P 4 / \mathrm{nmm}$ ) was used as a starting model. The refineable sample parameters were, therefore, restricted to cell edges, 


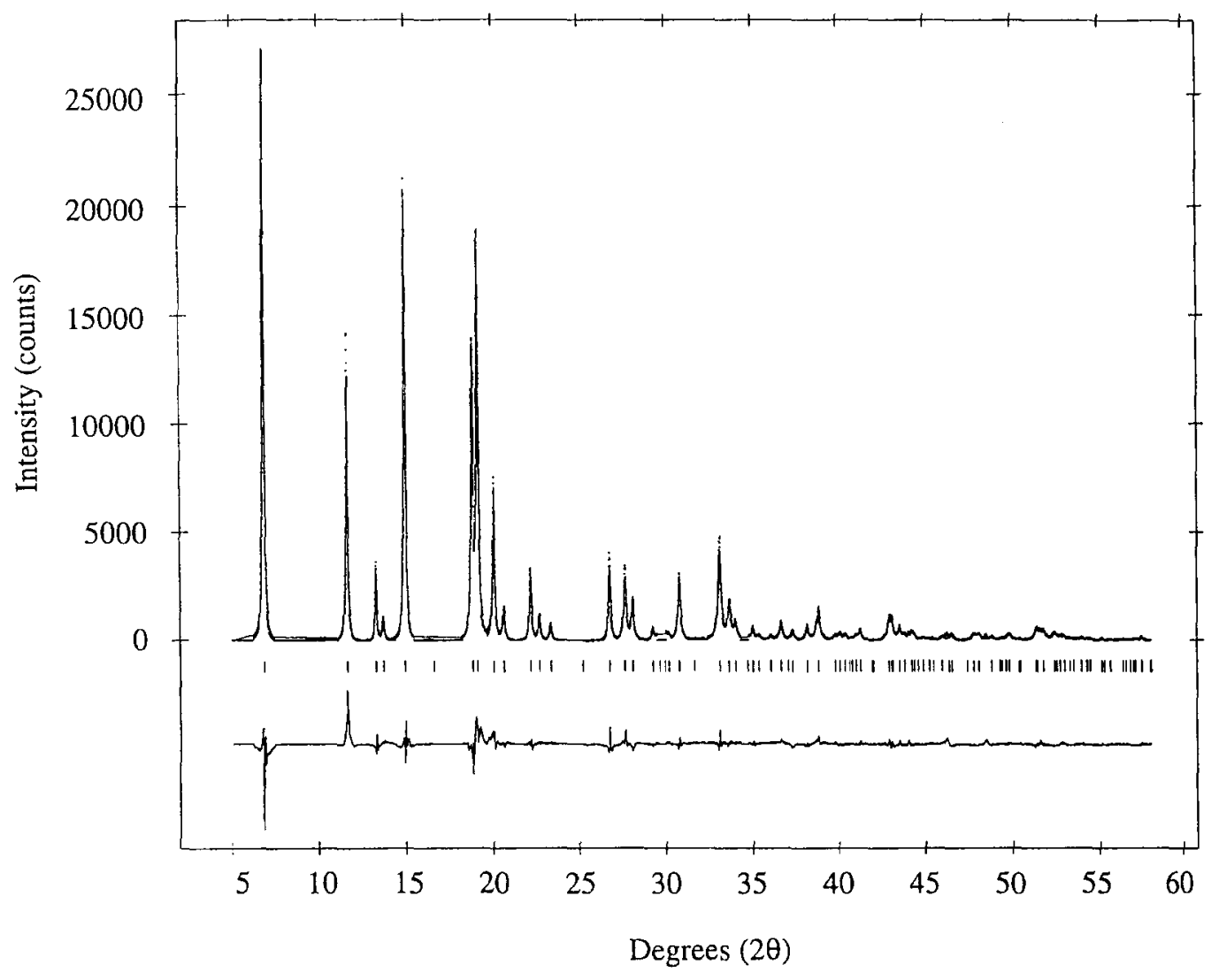

Fig. 1. X-ray diffraction (XRD) pattern of mackinawite obtained using synchrotron radiation. The difference between observed and Rietveld calculated intensities is shown below the XRD pattern.

TABLE 3. Refined structure parameters for synthetic mackinawite. Errors $(\sigma)$ are in parentheses

Space group $\quad P 4 / \mathrm{nmm}$ (No. 129) origin at $\overline{4} m 2$

Cell parameters (Rietveld)

$$
\begin{array}{ll}
a(\AA \AA) & 3.6735(4) \\
b(\AA) & 3.6735(4) \\
c(\AA) & 5.0328(7) \\
V\left(\AA^{3}\right) & 67.914(24)
\end{array}
$$

Atomic positional parameters Fe in 2(a):

$x$
0
0

$y$
0
0.5

$\begin{array}{ll}z & B \text { (iso) } \\ 0 & 0.41(2) \\ 0.2602(3) & 0.20(2)\end{array}$

The structure was refined with the following $R$ factors: $R_{I}=9.15 \%$ $R_{p}=12.42 \%$ $R_{e}=4.39 \%$ isotropic temperature factors, and the $\mathrm{z}$-coordinate of the $S$ atom. The refinement converged to give the structural parameters and $R$ factors summarised in Table 3, where

$$
\begin{aligned}
& R_{I}=100 . \Sigma\left|I_{\mathrm{obs}}-I_{\text {calc }}\right| / \Sigma\left|I_{\mathrm{obs}}\right| \\
& R_{p}=100 . \Sigma\left|Y_{\mathrm{obs}}-Y_{\text {calc }}\right| / \Sigma\left|Y_{\mathrm{obs}}\right| \\
& \left.R_{e}=100 . \Sigma[N-P] / \Sigma\left|w . Y_{\mathrm{obs}}\right|\right]^{0.5}
\end{aligned}
$$

$\mathrm{I}_{\mathrm{obs}}$ and $I_{\text {calc }}$ are the observed and calculated intensities for Bragg reflections, and $Y_{\text {obs }}$ and $Y_{\text {calc }}$ are the observed and calculated intensities at each point in the diffraction pattern. $N$ is the number of points in the pattern, $P$ the number of parameters refined $([N-P]=4165$ in this case), and $w$ is the weight assigned to each step intensity. The relatively high values of $R_{I}$ and $R_{p}$ reflect the small deviations in sample height across the flat plate sample holder, which arose from the difficulties of sample loading. 
TABLE 4. Bond distances and angles for synthetic mackinawite. Errors $(\sigma)$ are in parentheses

\begin{tabular}{ll}
\hline $\begin{array}{l}\text { Bond distances }(\AA) \\
\mathrm{Fe}-\mathrm{S}\end{array}$ & $2.2558(9)$ \\
$\mathrm{Fe}-\mathrm{Fe}$ & $2.5976(3)$ \\
& \\
Bond angles $\left(^{\circ}\right)$ & $2 \times 109.0251$ \\
$\mathrm{~S}-\mathrm{Fe}-\mathrm{S}$ & $2 \times 109.6947$ \\
& $4 \times 90$ \\
$\mathrm{Fe}-\mathrm{Fe}-\mathrm{Fe}$ & $2 \times 70.3053$ \\
$\mathrm{Fe}-\mathrm{S}-\mathrm{Fe}$ & $2 \times 109.0251$ \\
&
\end{tabular}

The agreement between the observed and calculated profiles in the Rietveld difference plot is illustrated in Fig. 1.

This structural analysis is consistent with previous reports of the structure of mackinawite; we were not able to refine vacancy occupancy or surplus $\mathrm{Fe}$ occupancy with any degree of significance. This refinement does not, therefore, provide any further
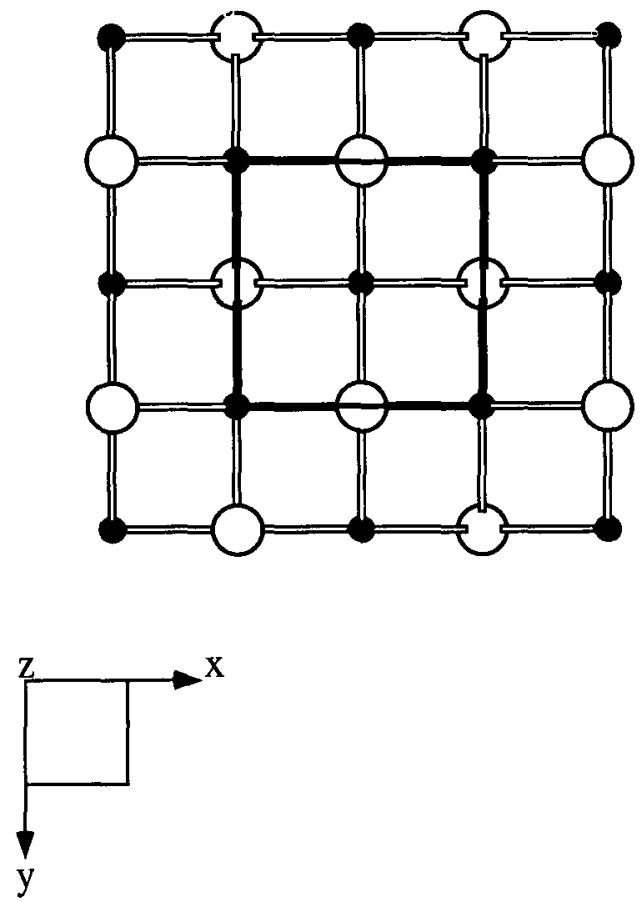

information on non-stoichiometry, either in terms of surplus $\mathrm{Fe}$, or $\mathrm{S}$-deficiency in the structure; a satisfactory refinement is achieved by assuming stoichiometric tetragonal FeS.

Comparing our refinement with the mackinawite structure of Uda (1968), we see that $S$ is significantly displaced from $z=0.25$. This has an impact on the resultant coordination environment (Table 4). Our refined structure shows that the $\mathrm{FeS}_{4}$ tetrahedron is very nearly perfectly regular, with two $\mathrm{S}-\mathrm{Fe}-\mathrm{S}$ bond angles which deviate only very slightly from the ideal tetrahedral bond angle. Each $\mathrm{S}$ is bonded to four $\mathrm{Fe}$ in an asymmetric one-sided four-fold coordination with $\mathrm{Fe}-\mathrm{S}-\mathrm{Fe}$ bond angles of $70^{\circ}$ and $109^{\circ}$, while the short $\mathrm{Fe}-\mathrm{Fe}$ distance of $2.5976 \AA$ (Fe in square planar coordination by $\mathrm{Fe}$ ) confirms the importance of $\mathrm{Fe}-$ Fe metallic bonding within the (001) layers (Fig. 2).

A listing of the $h k l$ Bragg reflections with associated interplanar spacings, and observed and calculated intensities obtained from this experiment, is given in Table 5 . When compared with previously reported data for this mineral (Berner, 1964; Uda, 1968), this tabulation provides a more extensive range of experimental $h k l$ intensity values, giving intensities of Bragg reflections out to $0.68 \AA$.
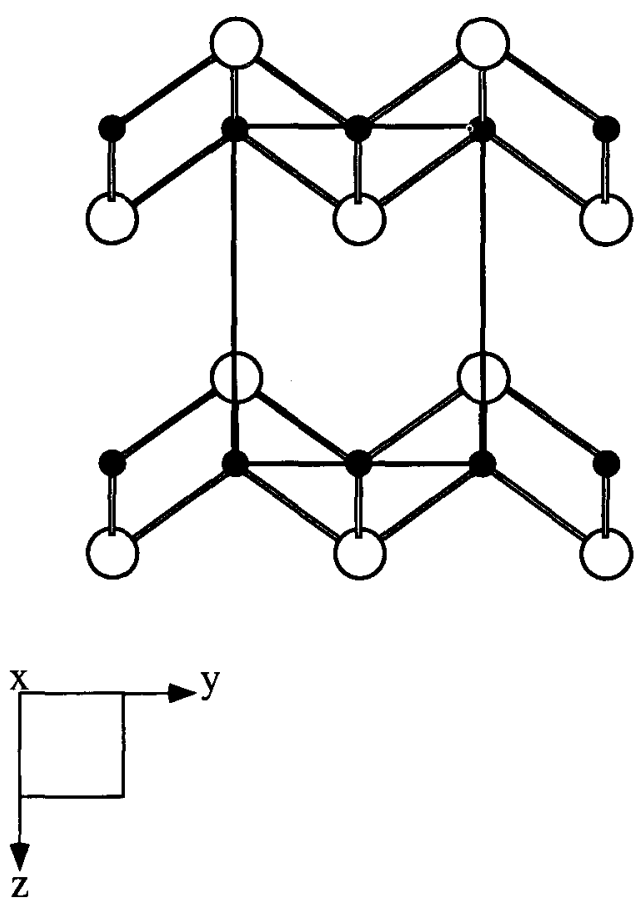

FiG. 2. Refined structure of mackinawite projected parallel to [001] (left) and [100] (right). Small filled spheres represent $\mathrm{Fe}$ atoms; large spheres represent $\mathrm{S}$ atoms. Fe-S bonds are shown, together with the outline of the unit cell. The structure comprises (001) sheets of edge-sharing $\mathrm{FeS}_{4}$ tetrahedra, with van der Waals bonding between sheets. 
TABLE 5. Powder diffraction pattern for mackinawite with intensities calculated using Rietveld refined parameters

\begin{tabular}{|c|c|c|c|c|c|c|c|}
\hline$h k l$ & $d(\AA)$ & $I_{\text {calc }}$ & $I_{\mathrm{obs}}$ & $h k l$ & $d(\AA)$ & $I_{\text {calc }}$ & $I_{\mathrm{obs}}$ \\
\hline 001 & 5.0328 & 100 & 100 & 402 & 0.8627 & $<1$ & $<1$ \\
\hline 101 & 2.9672 & 38 & 50 & 215 & 0.8583 & 2 & 2 \\
\hline 110 & 2.5976 & 8 & 8 & 314 & 0.8535 & $<1$ & 1 \\
\hline 002 & 2.5164 & 4 & 7 & 331 & 0.8533 & 2 & 2 \\
\hline 111 & 2.3082 & 64 & 70 & 412 & 0.8399 & $<1$ & $<1$ \\
\hline 102 & 2.0760 & $<1$ & $<1$ & 006 & 0.8388 & $<1$ & $<1$ \\
\hline 200 & 1.8368 & 37 & 38 & 420 & 0.8214 & 4 & 5 \\
\hline 112 & 1.8074 & 69 & 82 & 332 & 0.8187 & 4 & 5 \\
\hline 201 & 1.7254 & 23 & 29 & 106 & 0.8178 & $<1$ & $<1$ \\
\hline 003 & 1.6776 & 7 & 9 & 421 & 0.8107 & 3 & 3 \\
\hline 211 & 1.5617 & 11 & 12 & 403 & 0.8056 & 2 & 2 \\
\hline 103 & 1.5260 & 5 & 6 & 116 & 0.7982 & 4 & 4 \\
\hline 202 & 1.4836 & 3 & 4 & 225 & 0.7956 & 1 & 1 \\
\hline 212 & 1.3756 & $<1$ & $<1$ & 324 & 0.7918 & $<1$ & $<1$ \\
\hline 220 & 1.2988 & 12 & 11 & 413 & 0.7869 & 1 & 1 \\
\hline 004 & 1.2582 & 5 & 6 & 422 & 0.7809 & $<1$ & $<1$ \\
\hline 221 & 1.2576 & 8 & 9 & 305 & 0.7776 & 1 & I \\
\hline 203 & 1.2387 & 10 & 10 & 333 & 0.7694 & 1 & 2 \\
\hline 104 & 1.1903 & $<1$ & $<1$ & 206 & 0.7630 & $<1$ & $<1$ \\
\hline 301 & 1.1898 & 2 & 3 & 315 & 0.7607 & 3 & 4 \\
\hline 213 & 1.1738 & 5 & 6 & 216 & 0.7471 & $<1$ & $<1$ \\
\hline 310 & 1.1617 & 1 & 1 & 404 & 0.7418 & 3 & 2 \\
\hline 222 & 1.1541 & 1 & 1 & 423 & 0.7377 & 2 & 3 \\
\hline 114 & 1.1324 & 1 & 1 & 414 & 0.7271 & $<1$ & $<1$ \\
\hline 311 & 1.1319 & 12 & 14 & 501 & 0.7270 & $<1$ & 1 \\
\hline 302 & 1.1011 & $<1$ & $<1$ & 431 & 0.7270 & 1 & 1 \\
\hline 312 & 1.0547 & 23 & 26 & 510 & 0.7204 & $<1$ & $<1$ \\
\hline 204 & 1.0380 & 10 & 12 & 007 & 0.7190 & $<1$ & $<1$ \\
\hline 223 & 1.0270 & 5 & 6 & 325 & 0.7160 & 1 & 1 \\
\hline 005 & 1.0066 & 1 & 1 & 334 & 0.7133 & $<1$ & $<1$ \\
\hline 214 & 0.9989 & $<1$ & $<1$ & 511 & 0.7132 & 2 & 2 \\
\hline 321 & 0.9986 & 3 & 4 & 107 & 0.7056 & $<1$ & $<1$ \\
\hline 303 & 0.9891 & 1 & 2 & 502 & 0.7053 & $<1$ & $<1$ \\
\hline 105 & 0.9708 & 1 & 2 & 432 & 0.7053 & $<1$ & $<1$ \\
\hline 313 & 0.9550 & 4 & 6 & 226 & 0.7046 & $<1$ & $<1$ \\
\hline 322 & 0.9444 & $<1$ & $<1$ & 117 & 0.6929 & $<1$ & $<1$ \\
\hline 115 & 0.9386 & 4 & 4 & 512 & 0.6926 & 4 & 5 \\
\hline 400 & 0.9184 & 3 & 4 & 306 & 0.6920 & $<1$ & $<1$ \\
\hline 224 & 0.9037 & 6 & 8 & 424 & 0.6878 & 4 & 4 \\
\hline 401 & 0.9035 & 2 & 3 & 316 & 0.6800 & 4 & 3 \\
\hline 205 & 0.8827 & 1 & 2 & & & & \\
\hline 304 & 0.8775 & $<1$ & $<1$ & & $\cdot$ & & \\
\hline 411 & 0.8773 & 2 & 2 & & & & \\
\hline 323 & 0.8708 & 2 & 2 & & & & \\
\hline 330 & 0.8659 & $<1$ & $<1$ & & & & \\
\hline
\end{tabular}




\section{Acknowledgements}

Paul Lithgoe and Tim Jenson are thanked for analyses of mackinawite. Graham Bushnell-Wye and Tony Bell provided valuable assistance with collection of powder diffraction data and the Rietveld refinement respectively. This research was supported by NERC, and by a SERC small grant (number 22/ 258) for synchrotron studies.

\section{References}

Berner, R.A. (1962) Tetragonal FeS, a new iron sulfide. Science, 137, 669.

Berner, R.A. (1964) Iron sulfides formed from aqueous solution at low temperatures and atmospheric pressure. J. Geol., 72, 293-306.

Bertaut, E.F., Burlet, P. and Chappert, J. (1965) Sur l'absence d'ordre magnetique dans la forme quadratique de FeS. Solid State Comm., 3, 335-8.

Clark, A.H. (1966) Some comments on the composition and stability relations of mackinawite. Neues Jahrb. Mineral., Mh., 300-4.

Davison, W. (1991) The solubility of iron sulphides in synthetic and natural waters at ambient temperature. Aquatic Sciences, 53/4, 309-29.

Evans, H.T. Jr, Berner and R.A. \& Milton, C. (1962) Valleriite and mackinawite. Geol. Soc. America Program 1962, Annual Meeting, 47a.

Evans, H.T. Jr., Milton, C., Chao, E.C.T., Adler, I., Mead, C., Ingram, B. and Berner, R.A. (1964) Valleriite and the new iron sulfide, mackinawite. U.S. Geol. Surv. Prof. Pap., 475-D, 64-9.

Grønvold, F. (1968) Heat capacities and thermodynamic properties of the iron selenides $\mathrm{Fe}_{1.04} \mathrm{Se}, \mathrm{Fe}_{7} \mathrm{~S}_{8}$ and $\mathrm{Fe}_{3} \mathrm{Se}_{4}$ from 298 to $1050^{\circ} \mathrm{K}$. Acta Chem. Scand., 22, 1219-40.

Grønvold, F. and Westrum, E.F. Jr. (1959) Low temperature heat capacities and thermodynamic properties of the iron selenides $\mathrm{Fe}_{1.04} \mathrm{Se}, \mathrm{Fe}_{7} \mathrm{~S}_{8}$ and $\mathrm{Fe}_{3} \mathrm{Se}_{4}$ from 5 to $350^{\circ} \mathrm{K}$. Acta Chem. Scand., 13, 241-8.

Gronvold, F., Haraldsen, H. and Vihovde, J. (1954) Phase and structural relations in the system irontellurium. Acta Chem. Scand., 8, 1927-42.

Hagg, G. and Kindström, A.L. (1933) Röntgenuntersuchung am System Eisen-Selen. Z. physik. Chem., B, 22, 453-64.

Haraldsen, H., Grønvold, F. and Vihovde, J. (1944) Faseforholdene i systemet jern-tellur. Tidsskrf. Kjemi
Bergv., 4, 96-8.

Hoffmann, R. (1988) Solids and surfaces: A chemist's view of bonding in extended structures. VCH.

Kuovo, O., Vuorelainen, Y. and Long, J.V.P. (1963) A tetragonal iron sulfide. Amer. Mineral., 48, 511-24.

Lennie, A.R. (1994) Aspects of relations between metastable and stable phases in the iron-sulphur system. Unpublished PhD thesis, University of Manchester

Meyer, F.H., Riggs, O.L., McGlasson, R.I. and Sudbury, J.D. (1958) Corrosion products of mild steel in hydrogen sulfide environments. Corrosion, 14, 109-15.

Murray, A.D., Cockroft, J.K. and Fitch, A.N. (1990) Powder Diffraction Program Library (PDPL). University College, London.

Sarkar, S.C. (1971) Mackinawite from the sulfide ores of the Singhbhum Copper belt, India. Amer. Mineral., 56, 1312-18.

Takeno, S. (1965a) A note on mackinawite (so-called valleriite) from the Kawayama mine. Japan. Geol. Rept. Hiroshima Univ., 14, 59-76.

Takeno, S. (1965b) Thermal studies on mackinawite. $J$ Sci. Hiroshima Univ. Ser. C, 4, 455-78.

Takeno, S. and Clark, A.H. (1967) Observations on tetragonal (Fe, Ni, Co) $)_{1+\mathrm{x}} \mathrm{S}$, mackinawite. J. Sci Hiroshima Univ. Ser. C, 5, 287-93.

Takeno, S., Moh, G.H. and Wang, N. (1982) Dry mackinawite syntheses. Neues Jahrb. Mineral., Abh., 144, 291-342.

Taylor, L.A. and Finger, L.W. (1970) Structural refinement and composition of mackinawite. Carnegie Institute of Washington Geophys. Lab. Ann. Rept. $69,318-22$

Tsuji, T., Howe, A.T. and Greenwood, N.N. (1976) The $\mathrm{Fe}-\mathrm{Se}$ system. I. Mössbauer spectra and electrical conductivity of $\mathrm{Fe}_{1.04} \mathrm{Se}$. J. Solid State Chem., 17, 157-63.

Uda, M. (1968) The structure of tetragonal FeS. $Z$. anorg. Chem., 361, 94-8.

Vaughan, D.J. and Craig, J.R. (1978) Mineral chemistry of metal sulfides. Cambridge University Press.

Yamaguchi, S. and Moori, T. (1972) Electrochemical synthesis of ferromagnetic $\mathrm{Fe}_{3} \mathrm{~S}_{4}$. J. Electrochem. Soc., 119, 1062.

Zôka, H., Taylor, L.A. and Takeno, S. (1972) Compositional variations in natural mackinawite and the results of heating experiments. J. Sci. Hiroshima Univ., Ser. C, 7, 37-53.

[Manuscript received 24 January 1995:

revised 6 April 1995] 